九州大学学術情報リポジトリ

Kyushu University Institutional Repository

\title{
COMPLICATED ROUTES OF THE SYNHOSPITALIC PAIRS OF THE GENUS COLOCASZOMYZA IN JAVA, WITH DESCRIPTIONS OF TWO NEW SPECIES (DIPTERA, DROSOPHILIDAE)
}

Yafuso, Masako

Okada, Toyohi

https://doi.org/10.5109/2536

出版情報: ESAKIA. Special Issue 1, pp.137-150, 1990-04-20. Entomological Laboratory, Faculty of Agriculture, Kyushu University バージョン:

権利関係 : 


\title{
COMPLICATED ROUTES OF THE SYNHOSPITALIC PAIRS OF THE GENUS COLOCASIOMYIA IN JAVA, WITH DESCRIPTIONS OF TWO NEW SPECIES (DIPTERA, DROSOPHILIDAE)
}

\author{
M ASAKO YAFUSO \\ Entomological Laboratory, College of Agriculture, \\ University of the Ryukyus, Okinawa, 903-01 Japan \\ and \\ Tочоні OKaDA \\ Gotokuji Z-30-18, Setagaya-ku, Tokyo, 154 Japan
}

\begin{abstract}
A new synhospitalic couple of the genus Colocasiomyia de Meijere, C. xanthogaster and C. heterodonta, breeding in the inflorescences of the genera Homalomena and Aglaonema (Araceae) are described. New host plants of Colocasiomyia species are also reported with the population constitutions of the two couples in the host plants. Host preference and interspecific competition between females are also discussed.
\end{abstract}

In total 16 species of the genus Colocasiomyia de Meijere have hitherto been described from the area ranging from wet tropical to subtropical regions (Duda, 1923, 1924a ;Okada, 1975, 1980, 1986a, b, 1987 ; Carson \& Okada, 1980 ; Toda \& Okada, 1983 ;Okada \& Yafuso, 1989) (Fig. 1). Of which, some synhospitalic pairs have been known to breed in the dichogamous flowers of the family Araceae (Okada, 1975, 1986a, b, 1987, 1988 ; Carson \& Okada, 1980, 1982 ; Toda \& Okada, 1983 ;HondaYafuso, 1983 ; Yafuso \& Okada, 1989) (Fig. 1, shadowed species).

These flies have been known as pollinators (Carson \& Okada, 1980 ; Kramadibrata \& Hambali, 1983), showing modification of some morphological characters, such as bristles, adaptive to the specialized habits (Okada\& Carson, 1980). The most interesting biological subjects in the Colocasiomyia species would, however, be the analytical approaches for the male and female reproductive success of the hermaphrodite flowers through pollination and for the mechanism that permits the complex to coexist in a host flower.

In this paper, we will describe two new species of Colocasiomyia associated with flowers of the genera Homulomena and Aglaonema. We also present some new data on the breeding habits of the four species of Colocasiomyia : colocasiae (Duda), diconica (Toda \& Okada) and the two new species.

\section{Materials and Methods}

The collection and observations were made on 2-4 November, 1988 at the Bogor Botanical 


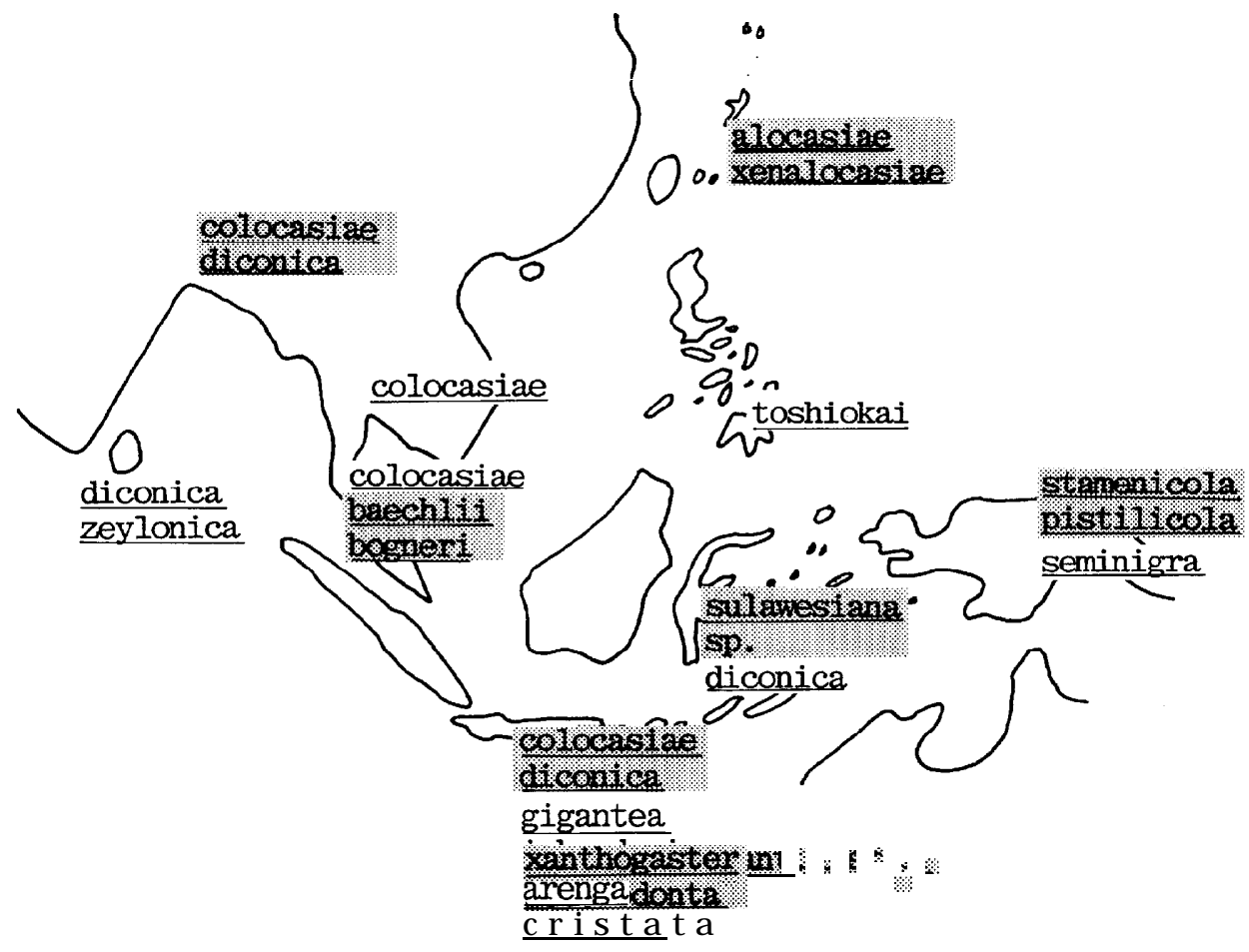

Fig. 1. Distribution of the 18 species of the genus Colocasiomyia, shadowed : synhospitalic pairs.

Garden, Bogor, Java. When young inflorescences of the family Araceae were found, each of them was covered with gauze net to aspirate adult flies directly. Later the fly-flowers, buds, and fruits were cut and preserved individually in the plastic bag filled with $70 \%$ alcohol to return to the laboratory of the University of the Ryukyus, Japan. It was impossible to count the number of larvae of Colocasiomyia diconica because of the bad condition of the specimens. One adult female of a new species, C. xanthogaster, was dissected for examining egg morphology under binocular microscope. Some females of C. diconica were also dissected to examine the fecundity potential and ovovivipality.

\section{Results}

1. Descriptions of the two new species.

\section{Colocasiomyia xan thogas ter n. sp.}

Male and Female (Fig. 2A-E).

Body 1.5-1.8 mm in length. Eye (Fig. 2B) oval, dark reddish purple, bare. Second antenna1 joint grey, third black. Arista with 1-2 dorsal and 1 ventral long branches and a large fork. Palpus black. Ocellar triangle large, black. Frons grey, anteriorly orange grey. Periobit black. Face grey, carina large, bulvous. Clypeus grey. Cheek black, very broad, as broad as eye diameter. Anterior reclinate orbital fine. Only one long oral. Mesoscutum mat black, yellowish below. Scutellum mat black. Thoracic pleura yellowish, black below. Humerals 2, long. Acrostichal hairs in about 2 rows. 


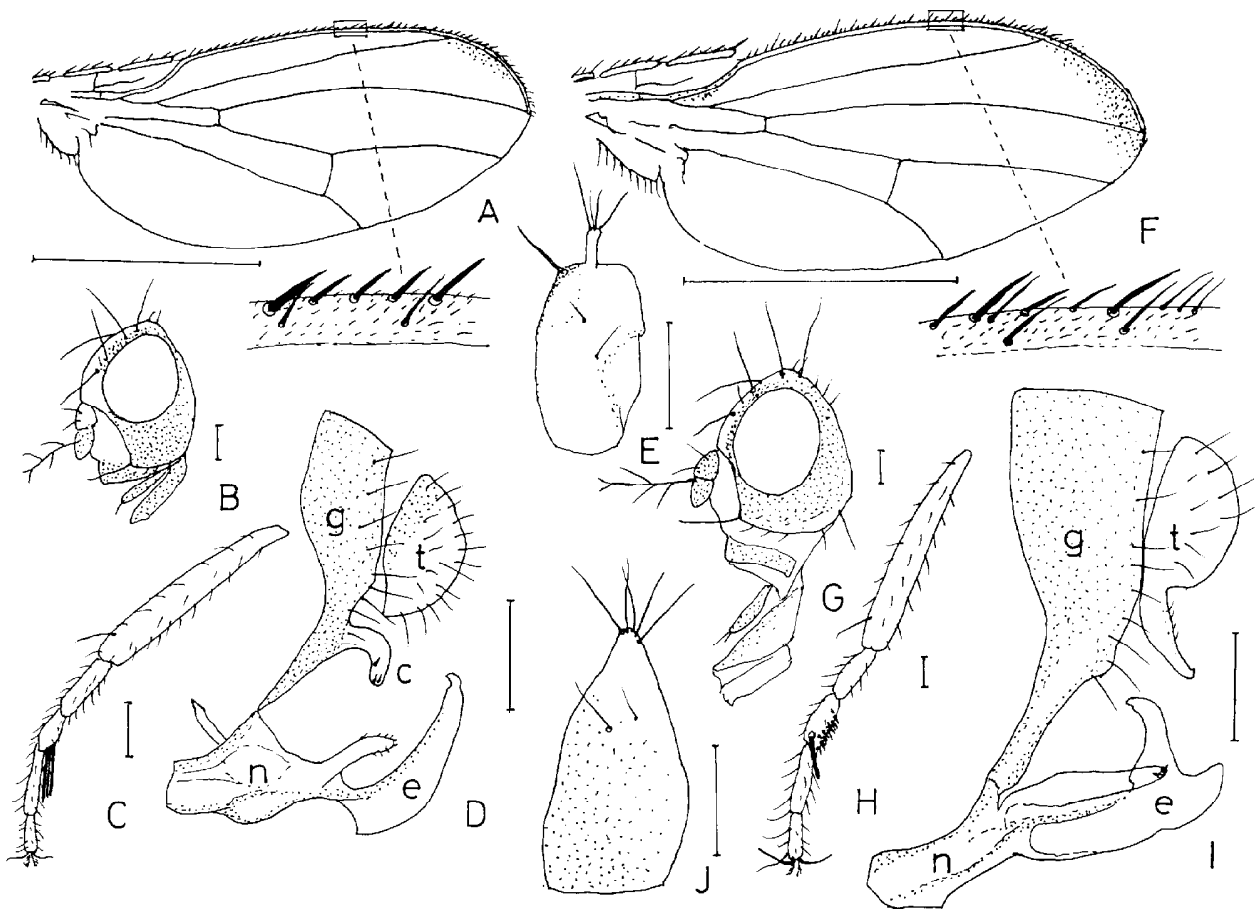

Fig. 2. A-E, Colocasiomyia xanthogaster; F-J, C. heterodonta. A, F, wing ; B, G, head; C, H, fore tarsi ; D, I, periphallic organs ; E, J, ovipositor. c, surstylus; e, aedeagus ; g, epandrium ; n, apodeme of aedeagus ; $t$, cercus.

Anterior dorsocentrals about $2 / 3$ posteriors. Scutellars somewhat divergent, laterals $1 / 2$ apicals. Sterno-index 1.0. Legs (Fig. 2C) yellow. $f,=t_{2-3}, f_{2,3}=t_{2-4}$. Second tarsal joint of fore leg apically with 3 long stout black bristles. Preapicals on all tibiae, apicals on 2nd. Wing (Fig. 2A) hyaline, apically somewhat fuscous. Costa1 bristles stout and thickly arranged (costal chaetotaxy type $\mathrm{B}_{2}$ ). C-index 2.8, 4V-index 1.4, 4C-index 0.9, 5x-index 1.2, Ac-index 2.4, C3-fringe about 1/3. Halter yellow, knob black, rounded. Abdominal tergites yellow, thus the specific name. Male $6 \mathrm{~S}$ without special process. Periphallic organs (Fig. 2D) : genital arch narrowly elongate caudally below. Surstylus curved, with 3 sensilla. Phallic organs (Fig. 2D) : aedeagus tapering distally and clawed apically. Ovipositor (Fig. 2E) elliptical, apically with a long seta and a fringe-like hairy process.

Egg (Fig. 3A).

About 0.6-0.7 $\mathrm{mm}$ in length. Narrowed below the terminal disc. Terminal disc triangular, with a short filament.

Larva (Fig. 4A-C).

Estimated to be xanthogaster. Caudal spiracles very short, completely separated at the base. Some rows of stout spines on the body wall.

Holotype $o^{7}$, allotype $q, 29$ paratypes, Bogor, Java, 3. XI. 1988, Yafuso leg. ex flowers of Homalomena sp. (holotype and allotype), H. pendula (Q paratype) and Aglaonema pictum ( $\$$ paratype) (Araceae).

RELATIONSHIPS : This species resembles C. toshiokai Okada in having plumose arista, long stout bristles of male fore leg, and in the shape of ovipositor, but differs by having heavy costal bristles 

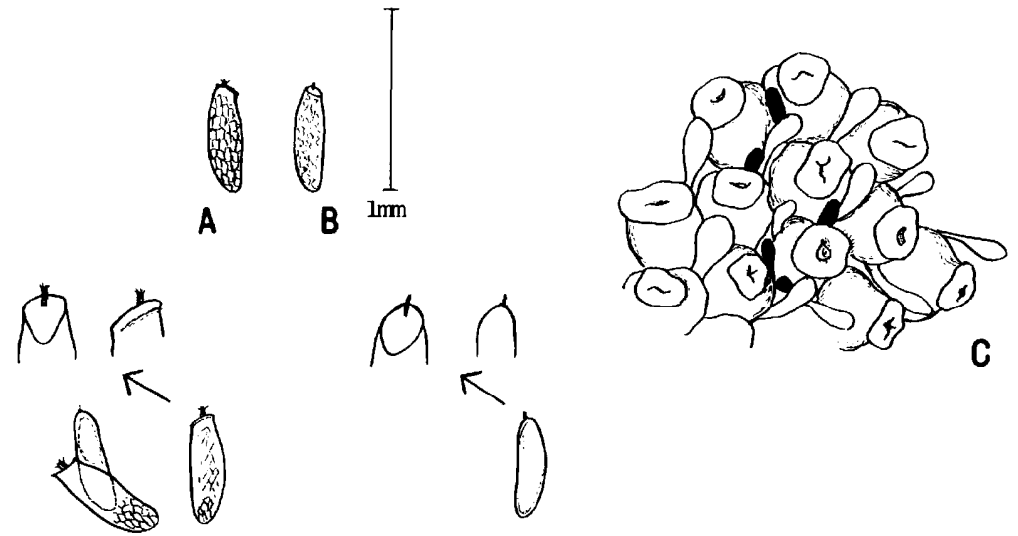

Fig. 3. A, egg of Colocasiomyia xanthogaster; B, egg considered to be C. heterodonta ; C, eggs of c. xanthogaster deposited among the pistillate flower of Homalomena sp. (solid ellipse).

(costal chaetotaxy type $\mathrm{B}_{2} ; \mathrm{B}_{0}$ in $\mathrm{C}$. toshiokai), minute anterior reclinate orbital bristles, and male cercus without ventral prolongation.

DisTRIBUTION : Java.

\section{Colocasiomyia he terodon ta $\mathrm{n} . \mathrm{sp}$.}

Male and female (Fig. 2F-J).

Body 1.5-2.0 mm in length. Eye (Fig. 2G) purple black, bare. Antenna black. Arista with 2 dorsal and 1 ventral long branches and a small fork. Palpus grey. Ocellar triangle mat brownish black. Frons mat brownish black. Face pale grey. Carina greyish white, bulbous. Clypeus black. Cheek black, nearly as broad as eye diameter. Anterior reclinate orbital minute. Vibrissae long, other orals fine. Mesoscutum and scutellum black, thoracic pleura yellowish white. Humerals 2, long. Acrostichal hairs in 2 rows. Anterior dorsocentrals as long as posteriors. Scutellars slightly convergent, laterals $1 / 3$ apicals. Sterno-index about 0.5. Legs yellow, second tarsal joint of fore leg (Fig. 2H) with a long apical bristle and about 12 smaller teeth in two rows (thus the specific name). Preapicals on all tibiae, apicals on second. Wing (Fig. 2F) hyaline, apically somewhat fuscous. Costa with sparcely arranged heavy setae (costal chaetotaxy type B,). C-index 2.0, 4V-index 1.4, 4C-index 1.0, 5x-index 1.8, Ac-index 2.4, C3-fringe 1/8. Halter black, stalk paler. Abdominal tergites black. Male 6S without special process. Periphallic organs (Fig. 21) : Epandrium elongate below ; surstylus triangular ; cercus narrowing ventrally. Phallic organ (Fig. 21) : aedeagus Y-shaped. Ovipositor (Fig. $2 \mathrm{~J}$ ) conical, apically with about 4 setae.

Egg (Fig. 3B).

About $0.67 \mathrm{~mm}$ in length. Terminal disc round. Surface sculpture a little weak when compared to C. xanthogaster. Gently convex ventrally.

Larva (Fig. 4D-F).

Supposed to be C. heterodonta. Caudal spiracles unforked. Many rows of fine spines on the body wall.

Holotype $\sigma^{\circ}$, allotype $\uparrow, 20^{`}$ paratypes, Bogor, Java, 3. XI. 1988, Yafuso leg. ex flowers of Homulomena sp. (holotype and allotype), H. pendula (ơ paratype) and Aglaonema pictum ( $\sigma^{\circ}$ paratype) (Araceae), collected together with the foregoing species.

Relationships. This species resembles C. bogneriOkada in the arrangement of heavy bristles 

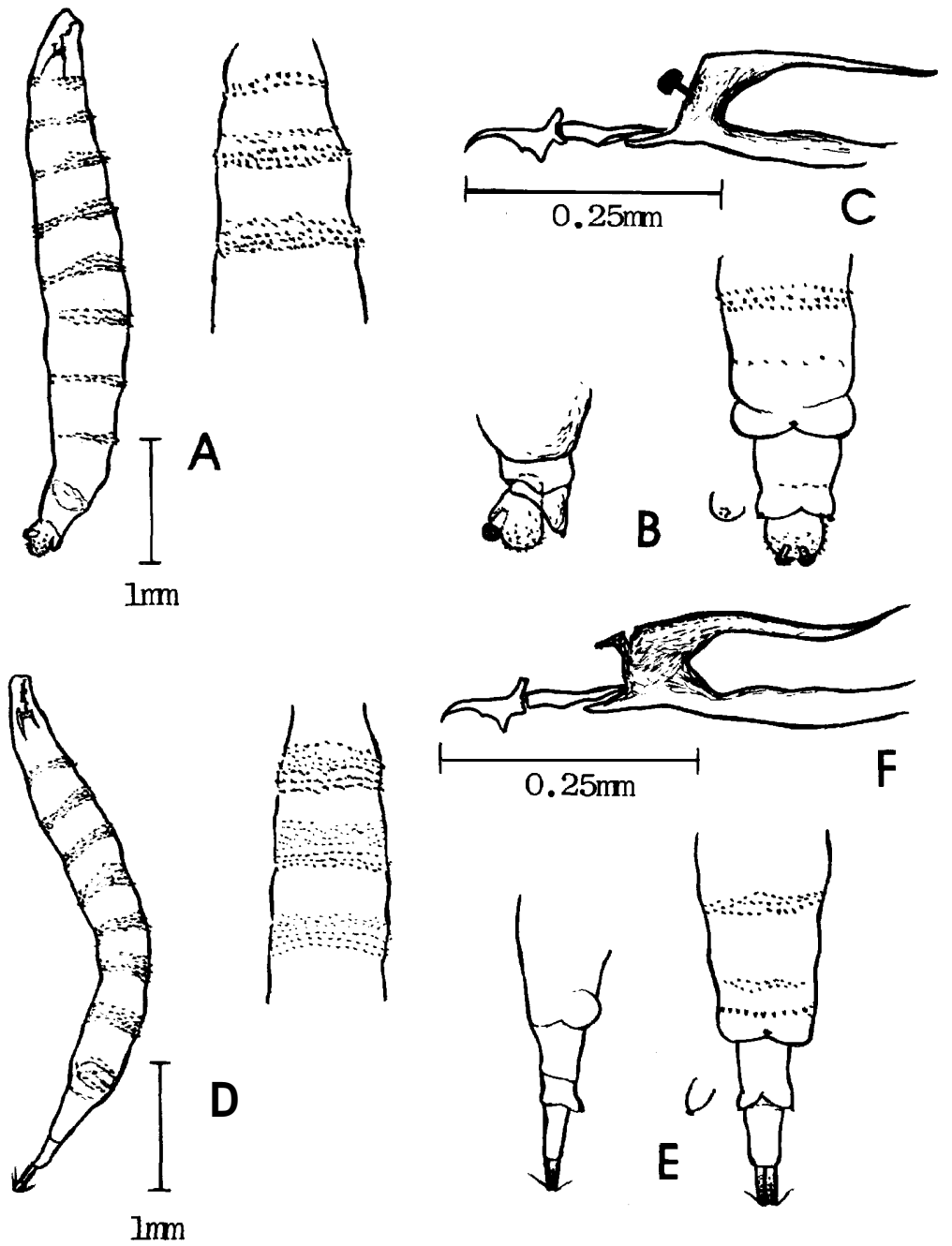

Fig. 4. Third instar larva and cephalopharyngeal skelton of Colocasiomyia xanthogaster (A-C) and C. heterodonta (D-F). A, D, lateral view (left) showing the rows of small spines on the body wall (right) ; B, caudal spiracles of C. xanthogaster very short, separated at the base ; E, the same of C. heterodonta not forked ; C, F, cephalopharyngeal skelton.

on the second tarsal joint of fore leg, but differs by having abdominal tergites yellow, wing tip cloudy, and costal setae stouter (costal chaetotaxy type $\mathrm{B}_{1} ; \mathrm{B}_{0}$ in bogneri).

Distribution : Java.

2. Host records.

Twelve flowering species of nine genera of Araceae were examined : Homalomena pendula, $\mathbf{H}$. sp., Aglaonema pictum, A. nitidum, A. sp., Xanthosoma sp., Alocasia macrorrhiza, Colocasia gigantea, Diffenbachia sp., Caladium bicolor, Monstera sp., and Spathiphyllum sp. Of which, 5 species of 4 genera were parasitized by Colocasiomyia species. Hitherto, Homalomenalancifolia from Malaysia and $\mathbf{H}$. sp. from Philippines have been known as the host species of Colocasiomyia. H. pendula (Photo 1) and 

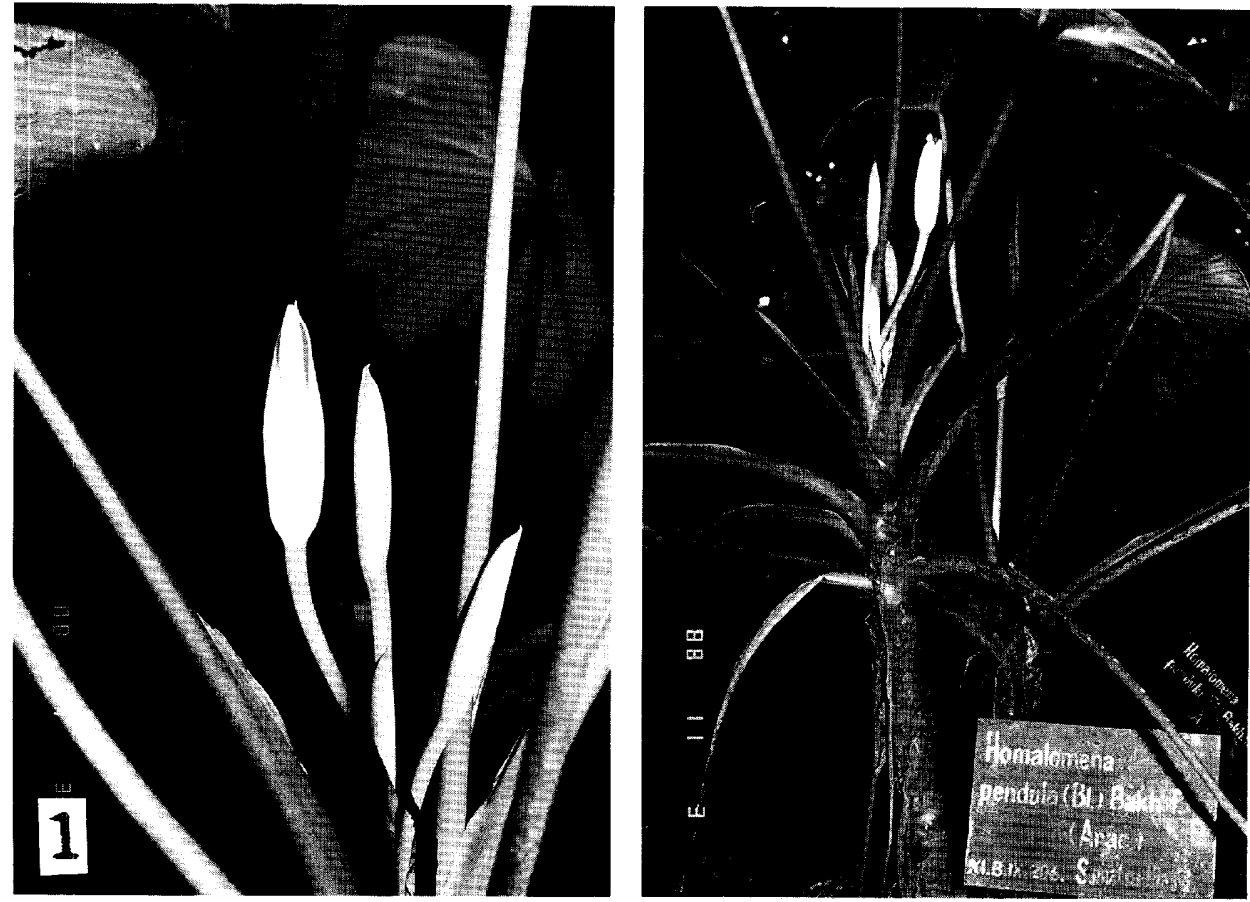

Photo 1. Homalomena pendula (B1.) Bakh f.
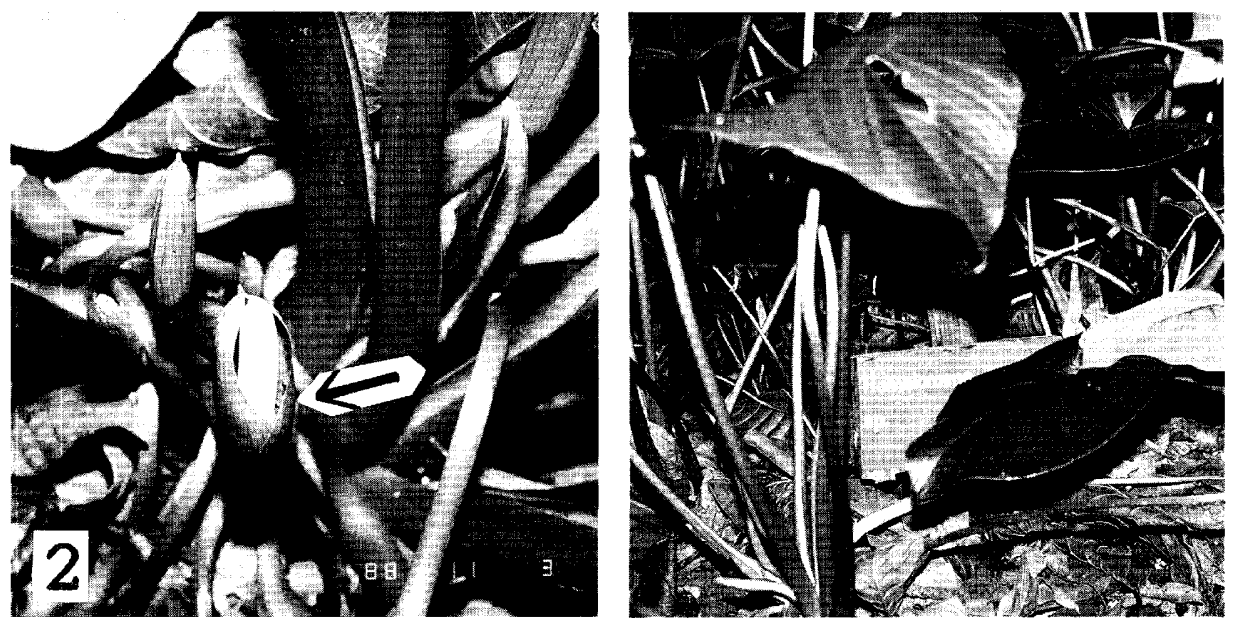

Photo 2. Homalomena sp. 

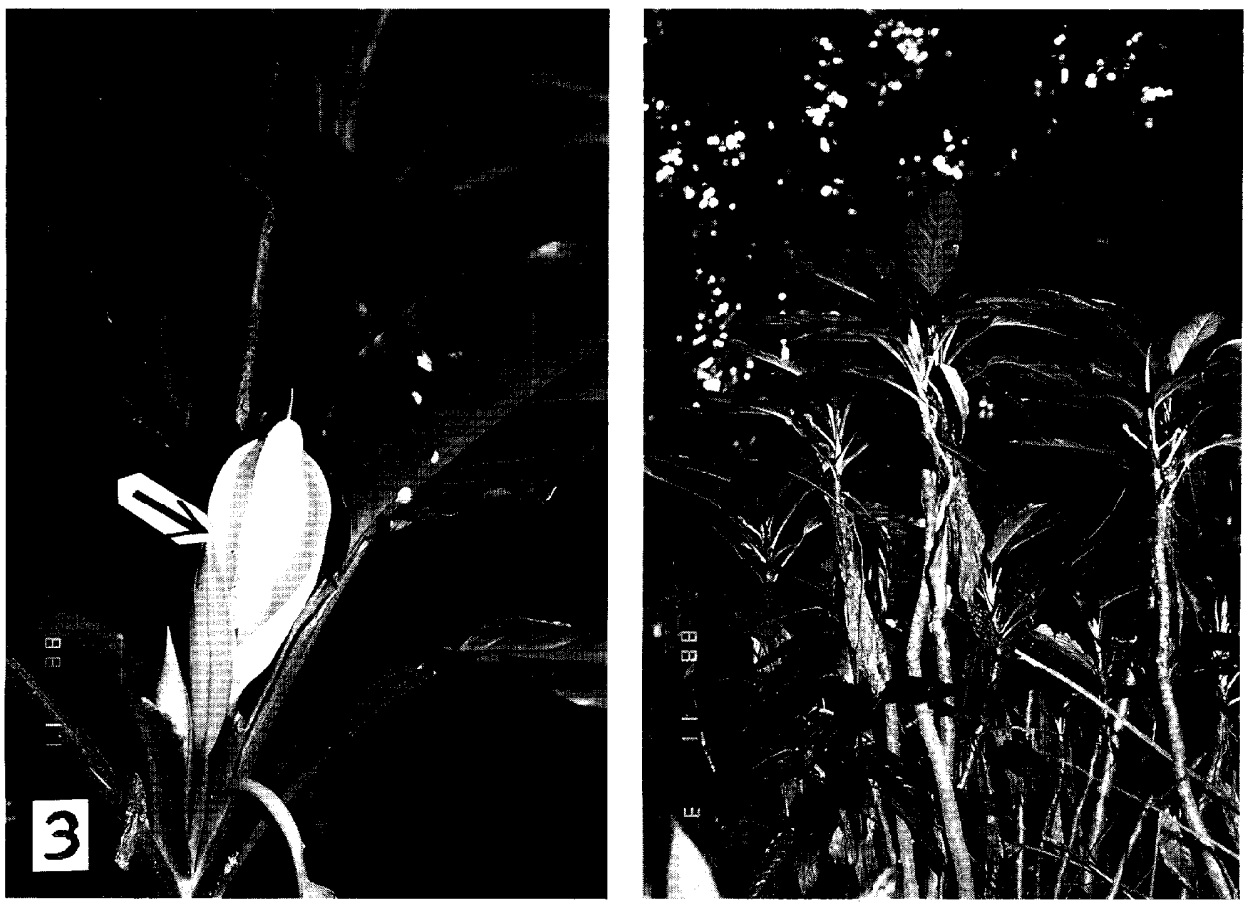

Photo 3. Aglaonema pictum Kunth. var. tricolor.
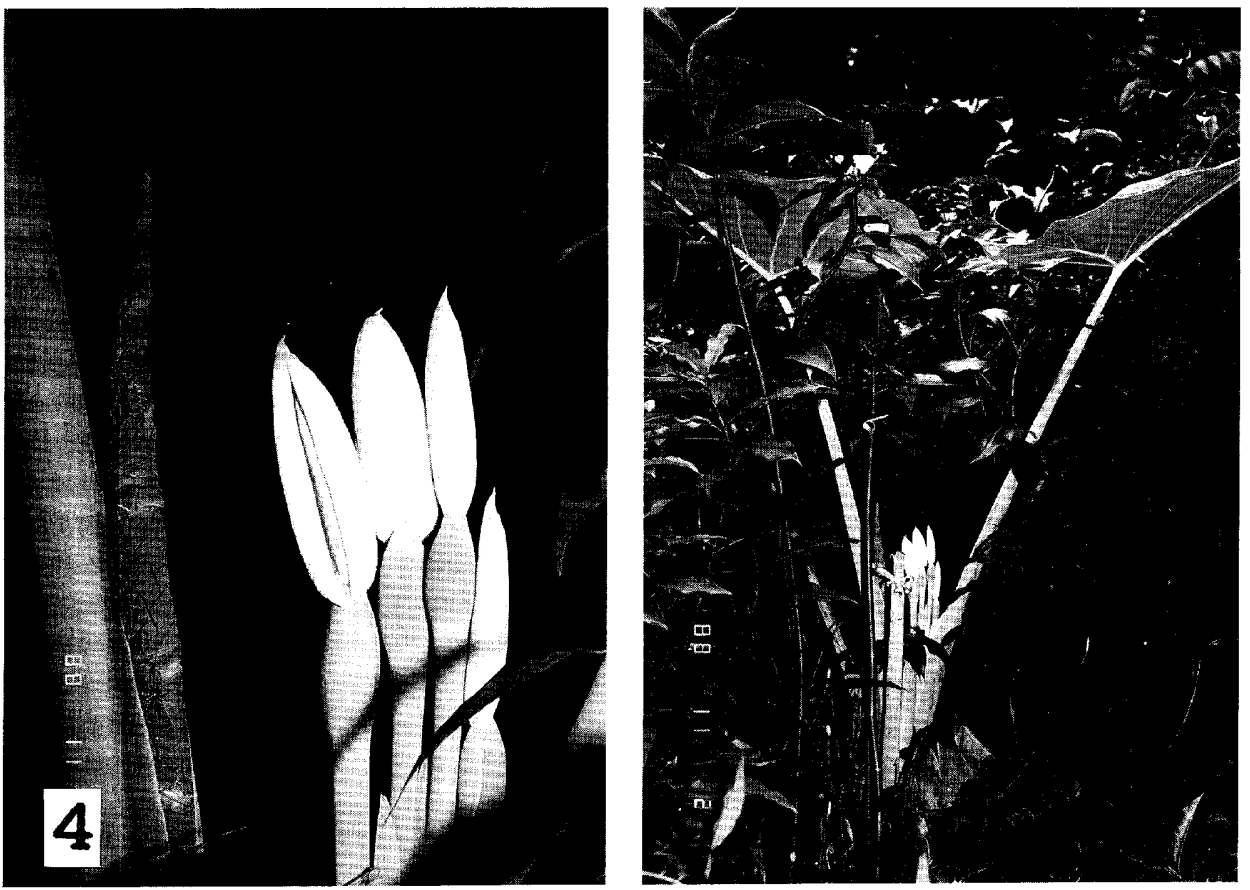

Photo 4. Colocasia sigantea Hook. f. 


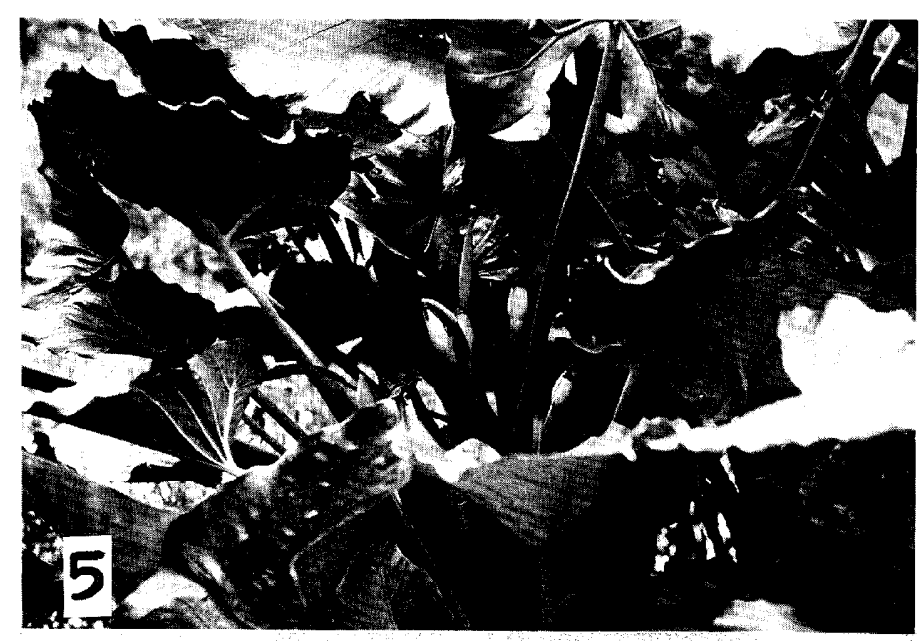

Photo 5. Alocasia macrorrhiza Schott.

H. sp. (Photo 2) were the host plant species of C.xanthogaster n. sp. and C. heterodonta n. sp. from Java in the present survey. Aglaonema pictum (Photo 3) was also recognized to rear the new couple mentioned here. The "Homalomena route", named by Okada (1986a), in Java was presently known. C. gigantea (Photo 4) has been recorded as the host plant of C. colocasiae and C. diconica from Java (Kramadibrata \& Hambali, 1983 ;Okada, 1987). Alocasiamacrorrhiza (Photo 5) was also the host plant of the diconica-colocasiae couple. This synhospitalic couple parasitized H. pendula, too. So that, the three distibution routes of "Homalomena route", "Colocasia route", and "Alocasia route" were clarified from Java.

3. Population constitutions.

A total of 17 inflorescences of the host plants of the "Homalomena route" were examined, 7 of which were parasitized by the synhospitalic pair of C. xanthogaster and heterodonta (Table 1). Adult flies of the two species were collected from 3 inflorescences. They were found together habouring on the inner wall of the spathe in the shadow part of spadix (Photos 2, 3). Morphologically different types of eggs were deposited on the flower. The egg of C. xanthogaster was identified by dissecting an adult female. The morphology of the terminal disc and chorion surface suggests that the other type is the eggs of C. heterodonta. We could not confirm it by dissecting, because we had only two female specimens. Of 68 C. xunthogaster eggs from 6 inflorescences, 64 (94.1\%) were collected from Homalomena flowers. Most of them were deposited in the pistillate portion. They were put individually among female flower in the spadix (Fig. 3C). Four eggs (5.9\%) out of 68 were found in the inflorescence of Aglaonema pictum. Of 35 heterodonta eggs, 16 (45.7\%) were found in the inflorescences of Homalomena sp. and 19 (54.3\%) in the inflorescences of Aglaonema pictum. Seven eggs out of $\mathbf{1 6}$ were deposited on the staminate portion and 9 on the pistillate portion. The average number of eggs per female was 1.6 in xunthogaster (68 eggs/6 females/3 inflorescences) and 5.8 in heterodonta (35 eggs/2 females/3 inflorescences) (Table 1). These values suggest that heterodonta might have larger fecundity than xunthogaster. All larvae of the two species were collected in the pistillate portion of the host inflorescences. The niche segregation between them was absent.

Another synhospitalic pair of C. diconica and C. colocasiae was also sampled from the inflorescences of C. gigantea, A. macrorrhiza and H. pendula in Bogor. Population constitution of the pair was very different from data so far presented (Table 2). Forty two females and forty four males 
Table 1. Population constitution of Colocasiomyia xanthogaster and C. heterodonta in the spadices of Araceae, Bogor, Java, 2-4 Nov., 1988.

\begin{tabular}{|c|c|c|c|c|c|c|c|c|c|}
\hline \multirow[b]{2}{*}{ Host No. } & \multirow[b]{2}{*}{ Host species } & \multirow[b]{2}{*}{ Stage* } & \multirow[b]{2}{*}{ Portion* . } & \multicolumn{3}{|c|}{ xanthogaster } & \multicolumn{3}{|c|}{ heterodonta } \\
\hline & & & & egg & $\begin{array}{c}\text { larva } \\
\text { (estimated) }\end{array}$ & adult & egg & $\begin{array}{l}\text { larva } \\
\text { (est.) }\end{array}$ & adult \\
\hline \multicolumn{2}{|c|}{$\begin{array}{c}\text { 11-1, } 2 \text { Homulomena } \\
\text { pendula }\end{array}$} & III & $\mathrm{P}$ & 1 & 6 & & \multicolumn{3}{|c|}{4} \\
\hline $40-1$ & Ditto & II & {$\left[\begin{array}{l}\mathrm{s} \\
\mathrm{p}\end{array}\right.$} & 9 & & $10^{\top} 19$ & & & $10^{7}$ \\
\hline $35-1$ & Homalomena & & $\Gamma \mathrm{s}$ & 3 & & & & & \\
\hline & $\mathrm{sp}$ & I & L p & 2 & 8 & & 1 & 4 & \\
\hline-2 & & I & $\mathrm{P}$ & 2 & 22 & & & & \\
\hline-3 & & II & {$\left[\begin{array}{l}\mathrm{s} \\
\mathrm{p}\end{array}\right.$} & $\begin{array}{r}7 \\
40\end{array}$ & 1 & $20^{7} 4$ 우 & $\begin{array}{l}7 \\
8\end{array}$ & & 1001 우 \\
\hline $48-1$ & $\begin{array}{l}\text { Aglaonema } \\
\text { pictum }\end{array}$ & II & - & 4 & & 19 & 19 & & 19 \\
\hline
\end{tabular}

- , developing stages : I, bud; II, young flower; III, staminate portion of the spadix decaying ; IV, fruit. * *, s, staminate portion ; $p$, pistillate portion.

- , the spadix collected on the same stem.

Table 2. Population constitution of Colocasiomyia diconica and C. colocasiae in the spadices of Araceae, Bogor, Java, 2-3 Nov., 1988.

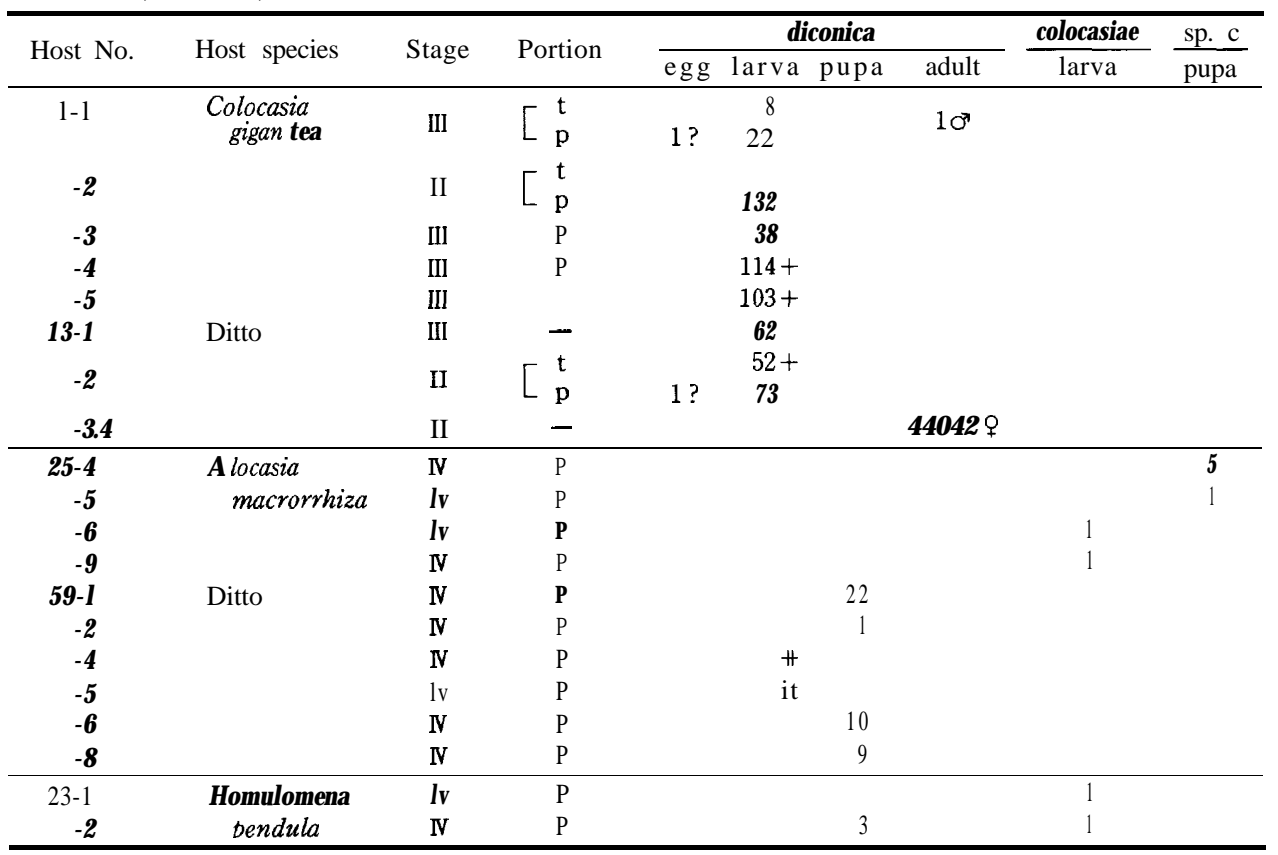

+ , more.

\#, many, but impossible to count because of bad condition of the specimens,

of diconica were aspirated from one young inflorescence of C. gigantea. Neither eggs nor young larvae were found here. A large number of larvae of diconica were obtained in other inflorescences of C. gigantea. They distributed from transitional region to pistillate portion in a spadix. No larva of other species was found. More than one hundred of larvae of diconica were also collected in the 

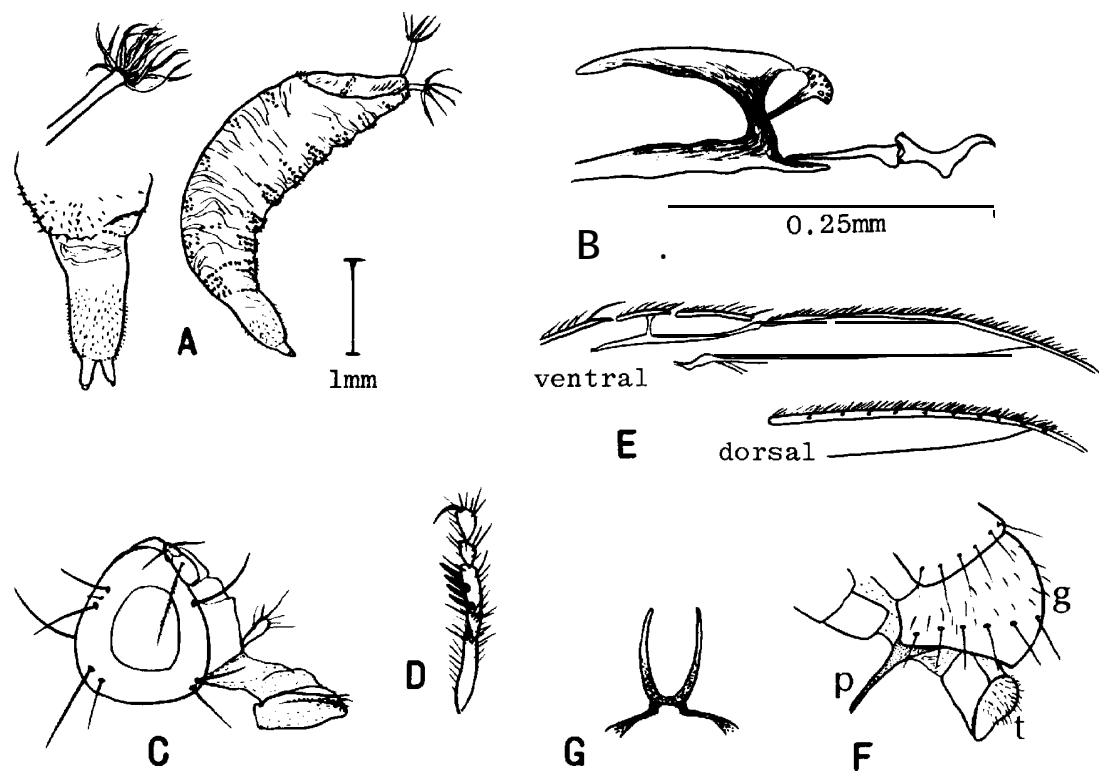

Fig. 5. Colocasiomyia sp. collected in the spadix of Alocasia macrowhiza in Stage IV. A, pupa ; B, cephalopharyngeal skelton left in the puparium ; C-G, pre-emerginal male found in the puparium. C, head ; D, fore tarsi ; E, costal chaetotaxy of fore wing ; F, periphallic organ ; G, abdominal process of the 6th abdominal sternite. $g$, epandrium ; $\mathrm{p}$, abdominal process of 6th sternite ; $t$,cercus.

Stage IV spadices of A. mucrowhiza. They were not together with other species as well as seen in C. gigantea. Forty two pupae of diconica were collected from 4 spadices of $\mathbf{A}$. macrowhiza where larvae were absent. Contrary to the large number of diconica, the extremely small number of colocasiae were obtained in the Stage IV spadices of $\mathbf{A}$. macrowhiza. They, 2 larvae, bred in the spadices where diconica was absent. No adult fly of colocasiae was caught. Eggs or pupae were also absent. Thus, diconica mostly occupied the spadices. The other species of the couple, colocasiae, did not share the habitats in C. gigantea and A. macrowhiza. One exceptional example of coexisting of the two species was seen in the Homalomena species. Three pupae of diconica and 1 larva of colocasiae coexisted in the Stage IV spadix of H. pendula. H. pendula was presently recorded as a common host plant species of the pair. The relationship between the two species on $\mathbf{H}$. pendula has not yet been known.

One unkonwn species of Colocasiomyia, named for convenience sp. C in Table 2, was found from the spadices of A. mucrowhiza. One pupa of 6 contained an adult male in the puparium. Figure 5 showed some morphological characters of the species. We would give a new name to this species when we could get much more specimens of adults and larvae. It was also unknown whether it has a synhospitalic mate.

\section{Discussion}

From the morphological characters such as spines on the bodywall or caudal spiracles, larvae with short, separated caudal spiracles and stout spines were considered to be xanthogaster, and larvae with unforked caudal spiracles and fine spines to be heterodonta, although it was not proved by 
rearing. Egg distribution in Table 1 suggested that xanthogaster was pistilicolous because their eggs were mostly deposited in the pistillate portion. While heterodonta might be stamenicolous, the half of whose eggs were found in the staminate portion. These two species might have different host preference though they parasitized the same host as a synhospitalic pair. That is, xanthogaster may prefer Homalomena species to Aglaonema, whereas Aglaonema may be favourable to heterodonta. A large number of eggs of xanthogaster on Homalomena may reflect their preference for Homalomena, and comparatively large number of eggs of heterodonta on Aglaonema suggest their preference of Aglaonema.

In the present survey in Bogor, the following two facts attracted our attention. The first one was that colocasiae was very few in number. Two larvae of colocasiae were hardly collected from $\mathbf{A}$. macrorrhiza but none of them from C. gigantea in spite that C. gigantea was also the host plant of this species and it grew up nearby A. macrorrhiza in the Garden. The second one was that the two species, diconica and colocasiae, might not share the larval niche in a spadix. It has been reported that the two species in Burma utilized the same host spadices of Colocasia esculenta altogether for oviposition site or larval niche though they shared the resource microallopatrically (Toda \& Okada, 1983). It was also described that many adult flies of the two species were collected simultaneously in the inflorescences of $C$. gigantea and C. esculenta in Java and Thailand (Okada, 1987). Contrary to this, 3 out of 4 larvae of colocasiae were collected in the spadices where diconica was absent.

These facts suggest the interspecific competition between females of the two species for oviposition site. To explain the exclusive or synhospitalic distribution of the two species in a host spadix,

Table 3. Ovarian condition of Colocasiomyia diconica harboured in the spadices of Colocasia gigantea, Bogor, 2-3 Nov., 1988, Java.

\begin{tabular}{|c|c|c|c|c|}
\hline \multirow{2}{*}{ No. } & \multicolumn{3}{|c|}{ No. of immature eggs } & \multirow{2}{*}{ Total } \\
\hline & left & & right & \\
\hline 1 & 2 & & $2+1 *$ & 5 \\
\hline 2 & 2 & & 2 & 4 \\
\hline 3 & 2 & & 2 & 4 \\
\hline 4 & 2 & & 1 & 2 \\
\hline 5 & $1+1^{*}$ & & 2 & 4 \\
\hline 6 & 3 & $1^{* *}$ & 3 & 7 \\
\hline \multirow[t]{2}{*}{7} & 1 & & 2 & 3 \\
\hline & $1.9 \mathrm{fo} .7$ & & $2.1 \pm 0.7$ & $4.1 \pm 1.6$ \\
\hline
\end{tabular}

*, mature egg containing the 1st instar larva ;

**, held in the common oviduct containing the 1st instar larva.

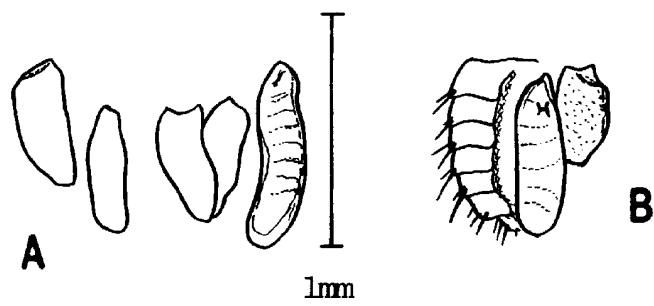

Fig. 6. Eggs of Colocasiomyia diconica. A, four immature eggs and one mature egg in the female specimen aspirated on the spadix of Colocasia gigantea ; B, a large mature egg in the female abdomen containing a full grown 1 st instar larva. 
the seasonal population density, host range and host preference should be examined.

Ovovivipality, low fecundity potential and alternating development of ovariole of flower-breeding drosophilids have been reported from Taiwan (Okada,1975), Burma (Toda \& Okada,1983), and Hawaii (Kambysellis \& Heed, 1971). It was also confirmed in diconica in Java (Table 3, Fig. 6).

Furthermore, the spadices of A. macrorrhiza which produced diconica larvae did not contained any pupae of the species, and conversely the spadices including pupae had not larvae. This analogous situation suggests that, as well as the synhospitalic pair of Papua New Guinea (Carson \& Okada, 1980), the females visited the host inflorescences for only a short time, perhaps one day. So that, the developing stage of diconica larvae was almost the same condition in an inflorescence. Although host plant flower provides the highly nutritious food, the restricted supply in abundance and short life span of a flower may be reflected in the short staying of these flies. They migrate to the next flower within a few days. In turn, it may be largely contribute to the allogamy of the host plant. Field observations in Okinawa suggest that alocasiae and xenalocasiae in Okinawa are strongly combined into the reproductive success of male of the hermaphlodite flower of A. odora (prep.). The species of Colocasiomyia associated with their host plants restrictedly.

Okada (1986a) estimated the three routes of synhospitalic distribution of the genus Colocasiaomyia in relation to the host plant distribution. They are : "Alocasia route" in Taiwan and Okinawa ; "Homalomena route" in Philippines and Malaysia ; "Colocasia route" in Burma, Malaysia, Java and Papua New Guinea. In the present survey, it was confirmed that "Homalomena route" and "Alocasia route" were also present in Java in addition to the known "Colocasia route" (Fig. 7). Furthermore, the colocasiae-diconica couple covered the three routes simultaneously in one area. All of the three routes were presently confirmed in Java. "Colocasia route" was also found in Sulawesi (prep.) as well as the "Alocasia route" (Okada \& Yafuso, 1989). Then, two of the three routes were

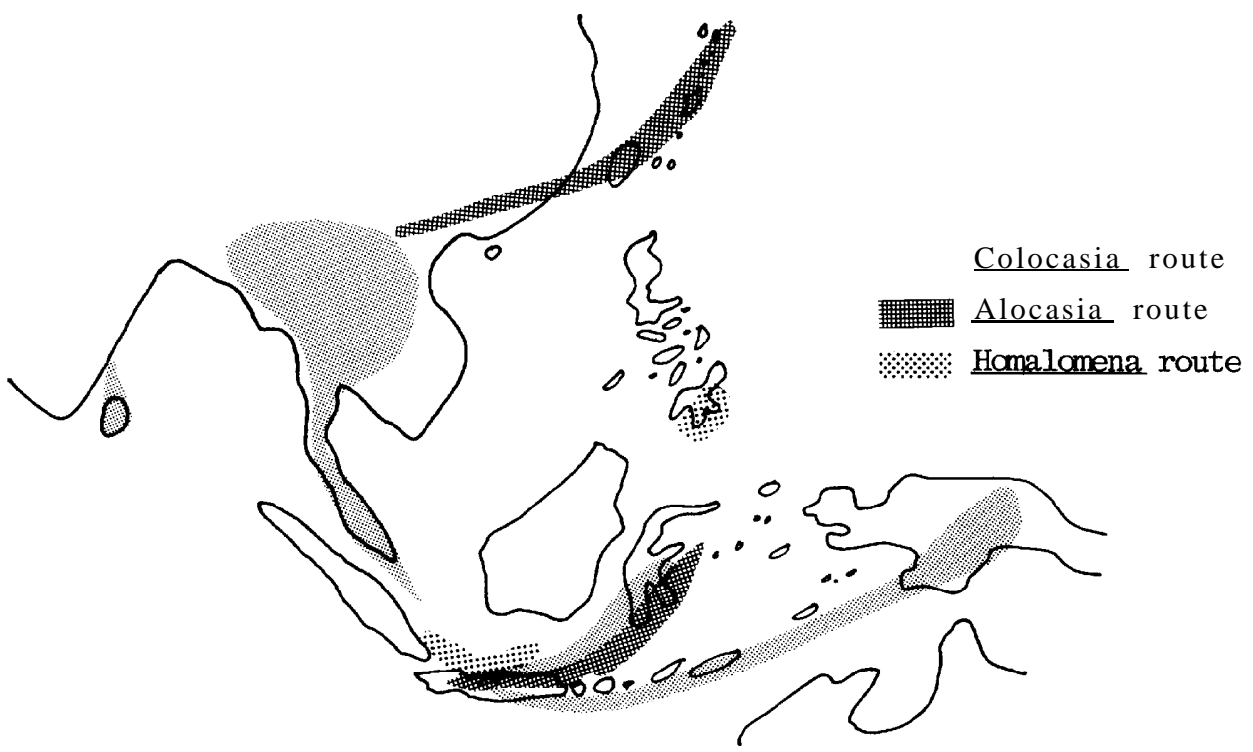

Fig. 7. Schema of the estimated host plant routes of the synhospitalic species of the genus Colocasiomyia, based on the hypothetical routes by Okada (1986a). The complicated routes in Java and Sulawesi were presently known. 
also cofirmed to be present in Sulawesi. These results indicated that the multiple Colocasiomyia fauna and the complicated relationship between host and synhospitalic flies would be found in Indonesia. It is predicted that many other new species or new couples of the genus should be found in this area. The old, intricated geographical history of Indonesia and the multiplicity of the fauna should greatly contribute to investigate the symbiosis and coevolution between plants and insects.

\section{Acknowledgement}

Our hearty thanks are due to Dr. Sampumo Kadarsan and Mr. Moh. Amid of the Bogor Botanical Garden, Java, for giving us permission of survery in the Bogor Botanical Garden. We also thanks to Dr. Mitsuru Hotta of Kagoshima University for identifying of some host plants.

\section{R eferences}

Carson, H. L. and T. Okada, 1980. Drosophilidae associated with flowers in Papua New Guinea I. Colocasia esculenta. Kontyû, Tokyo, 48(1): 15-29.

- 1982. Ecology and evolution of flower-breeding pamace flies of New Guinea (Diptera, Drosophilidae). Ent. General., 8(1): 13-16.

Duda, O., 1923. Die Orientalischen und Australischen Drosophiliden-Arten (Dipteren) des Ungarishen National-Museum zu Budapest. Ann. Mus. hist.-nat. hung., 20: 24-59.

— 1924a. Beitrag zur Systematik der Drosophiliden unter besonderer Berücksichtigung der paläarktischen und orientalischen Arten (Dipteren). Arch. Naturgesch., Abt. A, 90(3) : 172-234.

Honda-Y afuso, M., 1983. Interspecific relationship between synhospitalic Drosophilella species (Diptera, Drosophilidae) inhabiting Alocasia odora on Okinawa Is., Japan. Kontyâ, Tokyo, 51(4): 520-527.

Kambysellis, M. P. and W. B. Heed, 1971. Studies of oogenesis in natural populations of Drosophilidae. I. Relation of ovarian development and ecological habitats of the Hawaiian species. Amer. Natur., 105(941) : 31-49.

Kramadibrata, K. and G. G. Hambali, 1983. The roles of some insects in pollination of Colocasia esculenta var. esculenta and C. gigantea. Berira Biologi, 2(1) : 143-146 (In Indonesia).

Okada, T., 1975. The oriental drosophilids breeding in flowers. Kontya Tokyo, 43(3): 356-363. 1980. Synhospitalic evolution of the genus Drosophilella Duda (Diptera, Drosophilidae), with description of a new species from Okinawa and Taiwan. Ibid., 48(2): 218-225.

- 1986a. Estimation of the routes of synhospitalic distribution of the genus Drosophilella Duda (Diptera, Drosophilidae), with descriptions of three new species from Malaysia and Indonesia. Proc. Japn. Soc. syst. Zool., 33: 32-39.

- 1986b. Taximetrical analyses of costal chaetotaxy of the genus Drosophilella Duda, with description of a new species from Sri Lanka (Diptera, Drosophilidae). Ibid., 34 : 53-59.

— 1987. Further notes on the genus Drosophilella Duda with descriptions of two new species from Idonesia (Diptera, Drosophilidae). Ibid., 36 : 38-45.

— 1988. Taxonomic note on Colocasiomyia cristata de Meijere (Diptera, Drosophilidae) with generic synonymy. Ibid., 37 : 34-39.

— and H. L. Carson, 1980. Drosophilidae associated with flowers in Papua New Guinea II. Alocasia (Araceae). Pacific Insects, 22(3-4): 217-236.

Okada, T. and M. Yafuso, 1989. The genus Colocasiomyia Duda (Diptera, Drosophilidae) from Sulawesi. Proc. Japn. Soc. syst. Zool., 39: 48-55.

Toda, M. J. and T. Okada, 1983. Ecological studies of floricolous Drosophilella in Burma with 
descriptions of three new species from Burma and the Philippines (Diptera, Drosophilidae). Kontya, Tokyo, 51(2) : 169-184. 